УДК 595.76

Бєлявцев М. П. http://orcid.org/ 0000-0001-7074-5321

Мєшкова В.Л. http://orcid.org/ 0000-0001-6483-2736

\title{
КОМАХИ-КСИЛОФАГИ ЛИСТЯНИХ ПОРІД У НАЦІОНАЛЬНОМУ ПРИРОДНОМУ ПАРКУ «ГОМІЛЬШАНСЬКІ ЛІСИ»
}

\author{
(C) Бєлявцев М.П. ${ }^{1}$, Мєшкова В.Л. ${ }^{2}$
}

\author{
${ }^{1}$ Національний природний парк «Гомільщанські ліси»: e-mail: maksbelavcev@gmail.com \\ ${ }^{2}$ Украӥнський науково-дослідний інститут лісового господарства та агролісомеліорачї ім. \\ Г.М. Висоиького: \\ e-mail: ol.kukina@gmail.com; valentynameshkova@gmail.com
}

https://doi.org/10.34142/ 2708-583X.2019.21.10

\begin{abstract}
Метою досліджень було визначення екологічних особливостей $і$ оиінювання икідливості найбільш поширених комах-ксилофагів на території національного природного парку "Гомільшанські ліси». У листяних лісах парку виявлено 22 види комах-ксилофагів із 16 родів трьох родин: Вусачі (Сегатbусіdaе), Златки (Buprestidae) та підродини Короїди (Scolytinae) родини Довгоносики (Сиrсиlionidae). Переважна більшість виявлених видів є поліфагами. П'ять видів (Xуlotrechus antilope та златки роду Agrilus) виявлені лише на дубі, Dicerca (Dicerca) аепеа лише на в'язі, а решта - на різних листяних породах. Найбільш життєздатні дерева заселяли Scolytus intricatus i Agrilus biguttatus, а також - короїд родів Xyleborus i Xyleborinus. Bycaч Anisorus qиегсиs заселяв всихаючі дерева, а вусачі Роесіlium alni та Prionus coriarius - лише загиблі дерева. Виявлені види комах-ксилофагів за потенційною шкідливістю розподілені на чотири групи. Потениійно особливо шкідливими є чотири види (18,2\%) - A. biguttatus, S. intricatus, Xyleborus dispar ma Xyleborinus saxeseni, поширеність яких становила 7, 5, 1 і 1\% відповідно. Серед помірно шкідливих 9 видів (40,9\%) найбільш поширені Plagionotus arcuatus, P. detritus ma Saperda scalaris (nо 11 \%). Мало шкідлві - 5 видів, або 22,7\%, нешкідливі - 4 види, або 18,2\%. Серед особливо шкідливих видів Поширеність златки A. biguttatus та заболонника S. intricatus доволі висока (7 і 5 \% відповідно), а інших небезпечних видів X. dispar та X. saxеseni - низька (лише по $1 \%$ ). Серед помірно шкідливих видів найбільш поширені P. arcuatus, P. detritus ma S. scalaris (11 \%). Одержані дані $\epsilon$ підгрунтям для зіставлення у подальшому особливостей видового складу та шкідливості комах-ксилофагів на території начіонального природного парку, де виділені зони з різними режимами господарювання.
\end{abstract}

Ключові слова: вусачі, златки, короїди, шкідлвість, поширеність.

Національний природний парк категорія природно-заповідного фонду, що охороняється від більшості типів людської діяльності та забруднення [10]. Водночас на відміну від заповідників, у певних частинах національних парків дозволені господарська діяльність і рекреація. Як свідчать вітчизняні і зарубіжні дослідження [14, 18, 20, 22], будь-яка господарська діяльність і рекреація відбиваються на біорізноманітті та на стані окремих компонентів лісових екосистем. Однією з важливих складових лісових екосистем $є$ комахиксилофаги. Більшість із них залучені у природні цикли кругообігу речовини, оскільки $є$ першою ланкою освоєння мертвої деревини. Водночас деякі види вважають шкідниками, оскільки вони заселяють життєздатні дерева та прискорюють їхню загибель прямо або завдяки перенесенню збудників хвороб (фізіологічна шкода) або заселяють заготовлену деревину, що знижує іiї сортність і вартість $[9,11]$. Видовий склад комах-ксилофагів у Лівобережному лісостепу України взагалі $[2,6,13]$ та на території національного природного парку (НПП) «Гомільшанські ліси» зокрема 
$[3,4,12]$ висвітлений у публікаціях. Більшість із них не розглядали екологічні властивості окремих видів комах та їхню роль у лісах, де ведеться господарство чи інтенсивна рекреація. Інша група досліджень саме присвячена 3'ясуванню ролі ксилофагів в ослабленні дерев чи погіршенні якості заготовленої деревини [8, 11, 19, 21]. Метою цієї роботи було визначення екологічних особливостей i оцінювання шкідливості найбільш поширених комах-ксилофагів на території національного природного парку «Гомільшанські ліси».

\section{Матеріали і методи}

Дослідження проведені у 2019 р. у листяних насадженнях на території НПП «Гомільшанські ліси».

Обстеження здійснювали за маршрутними ходами 3 відстанню між ними 250-1000 м залежно від однорідності насаджень. Комах вивчали стандартними ентомологічними методами: косінням по трав'янистих рослинах, кущах i нижніх гілках дерев; оглядом заселених дерев та їхніх частин, ручним збиранням, вилученням передімагінальних стадій із кормового субстрату та виведення у лабораторії захисту лісу УкрНДІЛГА [7].

Виловлених i виведених імаго комах визначали в лабораторії за допомогою бінокулярного мікроскопу і порівнювали з екземплярами 3 колекції лабораторії захисту лісу УкрНДІЛГА та Харківського ентомологічного товариства.

Потенційну шкідливість окремих видів ксилофагів оцінювали за методичним підходом К.Г. Мозолевської [9] з урахуванням напрацю- вань попередніх років у Лівобережному Лісостепу [8, 11, 19, 21]. Згідно із цим оцінювали фізіологічну шкідливість кожного виду комах за спроможністю заселяти дерева різної категорії санітарного стану, спроможністю завдавати шкоди під час додаткового живлення та перенесення збудників хвороб дерев [15-17]. Технічну шкоду комах оцінювали 3 урахуванням заселеної деревної породи та частини стовбура, глибини руйнування деревини й ширини ходів. Під час визначення загальної шкідливості брали до уваги також кількість генерацій на рік [9]. Згідно з розрахованою сумою балів види розподіляли на особливо шкідливі, помірно шкідливі, мало шкідливі та нешкідливі. Поширеність кожного виду розраховували як його частку у зборах.

Стандартну похибку поширеності видів у зборах розраховували як для якісних ознак [1].

\section{Результати}

У результаті досліджень виявлено 22 види комах ряду Coleoptera (Твердокрилі), які належать до 16 родів родин Cerambycidae (Вусачi), Buprestidae (Златки) та підродини Короїди (Scolytinae) родини Довгоносики (Curculionidae) (табл. 1).

П'ять видів (вусач $X$. antilope та златки роду Agrilus sp.) виявлені нами лише на дубі, D. aenea - лише на в'язі. Більшість видів, наведених у табл. 1, виявляли на різних листяних породах.

Жоден вид стовбурових комах не заселяв здорових дерев, деякі види заселяли гілки ослаблених дерев або ділянки стовбурів поблизу механічних пошкоджень. Життєздатні дерева заселяли S. intricatus i 
A. biguttatus, а також - короїди родів Xyleborus sp. i Xyleborinus sp. Вусач

A. quercus - заселяв всихаючі дерева, а вусачі $P$. alni та P. coriarius - лише загиблі дерева.

\section{Трофічні зв'язки й топічна приуроченість комах-ксилофагів, виявлених у НПП «Гомільшанські ліси»}

\begin{tabular}{|c|c|c|c|c|}
\hline \multirow[b]{2}{*}{ Назва виду } & \multicolumn{3}{|c|}{ Заселені } & \multirow{2}{*}{$\begin{array}{l}\text { Додаткове } \\
\text { живлення }\end{array}$} \\
\hline & породи & $\begin{array}{c}\text { дерева за } \\
\text { станом }\end{array}$ & $\begin{array}{l}\text { частини } \\
\text { дерев }\end{array}$ & \\
\hline \multicolumn{5}{|c|}{ Родина Cerambycidae (Вусачi) } \\
\hline $\begin{array}{l}\text { 1. Prionus (Prionus) coriarius (Linnaeus, 1758) } \\
\text { - Пильчастовусий вусач }\end{array}$ & Дз, В3, Яз & мертві & стовбур & не має \\
\hline $\begin{array}{l}\text { 2. Anisorus quercus Goeze, } 1783 \text { - Стенокор } \\
\text { дубовий }\end{array}$ & Дз, В3, Яз & всихаючі & низ & не має \\
\hline $\begin{array}{l}\text { 3. Cerambyx scopolii Fuessly, } 1775 \text { - Малий } \\
\text { дубовий вусач }\end{array}$ & Дз, В3, Яз, Клг & $\begin{array}{c}\text { сильно } \\
\text { ослаблені }\end{array}$ & $\begin{array}{l}\text { весь } \\
\text { стовбур }\end{array}$ & квіти \\
\hline $\begin{array}{l}\text { 4. Phymatodes testaceus (Linnaeus, 1758) - } \\
\text { Фіматодес мінливий }\end{array}$ & Дз, В3, Яз & $\begin{array}{c}\text { сильно } \\
\text { ослаблені }\end{array}$ & $\begin{array}{l}\text { весь } \\
\text { стовбур }\end{array}$ & $?$ \\
\hline $\begin{array}{l}\text { 5. Poecilium alni (Linnaeus, 1767)- } \\
\text { Вільховий вусач }\end{array}$ & Дз, В3, Яз & мертві & гілки & не має \\
\hline $\begin{array}{l}\text { 6. Plagionotus detritus (Linnaeus, 1758)- } \\
\text { Смугастий дубовий кліт }\end{array}$ & Д3, В3 & $\begin{array}{l}\text { сильно } \\
\text { ослаблені }\end{array}$ & $\begin{array}{l}\text { весь } \\
\text { стовбур }\end{array}$ & $?$ \\
\hline $\begin{array}{l}\text { 7. Plagionotus arcuatus (Linnaeus, 1758) - } \\
\text { Строкатий дубовий кліт }\end{array}$ & Д3, В3 & $\begin{array}{c}\text { сильно } \\
\text { ослаблені }\end{array}$ & $\begin{array}{c}\text { весь } \\
\text { стовбур } \\
\end{array}$ & $?$ \\
\hline $\begin{array}{l}\text { 8. Xylotrechus antilope (Schönherr, 1817) - } \\
\text { Дубовий верхівковий кліт }\end{array}$ & Дз & $\begin{array}{c}\text { сильно } \\
\text { ослаблені }\end{array}$ & верx & $?$ \\
\hline $\begin{array}{l}\text { 9. Mesosa curculionoides (Linnaeus, 1761) - } \\
\text { Довгоносико-подібний очкастий вусач }\end{array}$ & Дз, В3, Бп & $\begin{array}{l}\text { сильно } \\
\text { ослаблені }\end{array}$ & $\begin{array}{c}\text { весь } \\
\text { стовбур }\end{array}$ & $?$ \\
\hline $\begin{array}{l}\text { 10. Leiopus nebulosus (Linnaeus, 1758) - } \\
\text { Сірий кленовий вусачик }\end{array}$ & Дз, Яз, Клг & $\begin{array}{l}\text { сильно } \\
\text { ослаблені }\end{array}$ & гілки & не має \\
\hline $\begin{array}{l}\text { 11. Saperda scalaris (Linnaeus, 1758) - } \\
\text { Мармуровий скрипун }\end{array}$ & Дз, Клг, Бп & $\begin{array}{l}\text { сильно } \\
\text { ослаблені }\end{array}$ & $\begin{array}{c}\text { весь } \\
\text { стовбур }\end{array}$ & лист \\
\hline \multicolumn{5}{|c|}{ Родина Buprestidae (Златки) } \\
\hline $\begin{array}{l}\text { 12. Dicerca (Dicerca) aenea (Linnaeus, 1766) } \\
\text { - Златка бронзова }\end{array}$ & $\mathrm{B} 3$ & $\begin{array}{c}\text { сильно } \\
\text { ослаблені }\end{array}$ & стовбур & листки \\
\hline $\begin{array}{l}\text { 13. Chrysobothris affinis (Fabricius 1794) - } \\
\text { Дубова бронзова златка }\end{array}$ & Дз, В3, Клг, Бп & $\begin{array}{c}\text { сильно } \\
\text { ослаблені }\end{array}$ & $\begin{array}{c}\text { весь } \\
\text { стовбур }\end{array}$ & листки \\
\hline $\begin{array}{l}\text { 14. Agrilus biguttatus (Fabricius 1777) - } \\
\text { Дубова двоплямиста вузькотіла златка }\end{array}$ & Дз & $\begin{array}{c}\text { сильно } \\
\text { ослаблені }\end{array}$ & стовбур & листки \\
\hline $\begin{array}{l}\text { 15. Agrilus angustulus (Illiger, 1803) - Златка } \\
\text { вузькотіла дубова верхівкова }\end{array}$ & Д3, В3, Бп & $\begin{array}{c}\text { сильно } \\
\text { ослаблені }\end{array}$ & гілки & листки \\
\hline $\begin{array}{l}\text { 16. Agrilus hastulifer (Ratzeburg, 1837) - } \\
\text { Шовковиста вузькотіла златка }\end{array}$ & Дз & $\begin{array}{c}\text { сильно } \\
\text { ослаблені }\end{array}$ & гілки & листки \\
\hline $\begin{array}{l}\text { 17. Agrilus laticornis (Illiger, 1803) - Златка } \\
\text { вузькотіла широковуса }\end{array}$ & Дз & $\begin{array}{c}\text { сильно } \\
\text { ослаблені }\end{array}$ & гілки & листки \\
\hline $\begin{array}{l}\text { 18. Agrilus sulcicollis Boisduval \& Lacordaire, } \\
1835 \text { - Златка дубова подовжена }\end{array}$ & Дз & $\begin{array}{c}\text { сильно } \\
\text { ослаблені }\end{array}$ & верх & листки \\
\hline \multicolumn{5}{|c|}{ Родина Curculionidae (підродина Scolytinae - Короїди) } \\
\hline $\begin{array}{l}\text { 19. Scolytus intricatus (Ratzeburg, 1837) - } \\
\text { Дубовий заболонник }\end{array}$ & Д3, В3 & $\begin{array}{c}\text { сильно } \\
\text { ослаблені }\end{array}$ & $\begin{array}{c}\text { гілки, } \\
\text { стовбур } \\
\end{array}$ & пагони \\
\hline $\begin{array}{l}\text { 20. Xyleborus dispar (Fabricius 1792) - } \\
\text { Західний непарний короїд }\end{array}$ & $\begin{array}{c}\text { Д3, В3, Я3, } \\
\text { Клг, БП }\end{array}$ & ослаблені & $\begin{array}{l}\text { гілки, } \\
\text { стовбур }\end{array}$ & в ходах \\
\hline $\begin{array}{l}\text { 21. Xyleborus monographus (Fabricius, 1792) - } \\
\text { Дубовий непарний короїд }\end{array}$ & В3, Яз & ослаблені & низ & в ходах \\
\hline $\begin{array}{l}\text { 22. Xyleborinus saxeseni (Ratzeburg, 1837) - } \\
\text { Непарний короїд }\end{array}$ & $\begin{array}{l}\text { Д3, В3, Я3, } \\
\text { Клг, Б3 }\end{array}$ & ослаблені & $\begin{array}{c}\text { весь } \\
\text { стовбур }\end{array}$ & в ходах \\
\hline
\end{tabular}

Примітка: Дз - дуб звичайний, Вз - в’яз, Яз - ясен звичайний, Клг - клен гостролистий, Бп - береза повисла. 
3 наведеного переліку комахксилофагів, виявлених нами у НПП «Гомільшанські ліси», 20 видів $\epsilon$ поширеними у Лівобережному лісостепу, й їхню потенційну шкідливість вже оцінювали [8]. Два види (один вусач i одна златка) входять до списку видів, які раніше виявляли у НПП «Гомільшанські ліси» [5]. Серед цих видів A. quercus заселяє всихаючі й мертві гілки і не здійснює додаткового живлення його можна вважати нешкідливим. Златка D. aеnea також заселяє сильно ослаблені дерева, але дані стосовно їі додаткового живлення та ролі у перенесенні збудників хвороб відсутні, тому ми умовно вважаємо іiі мало шкідливим видом.

Зважаючи на дослідження, проведені у попередні роки в Лівобережному лісостепу [8], та відомості про види, виявлені додатково у НПП «Гомільшанські ліси», виявлені комахи-ксилофаги за потенційною шкідливістю розподілені на чотири групи (рис. 1).

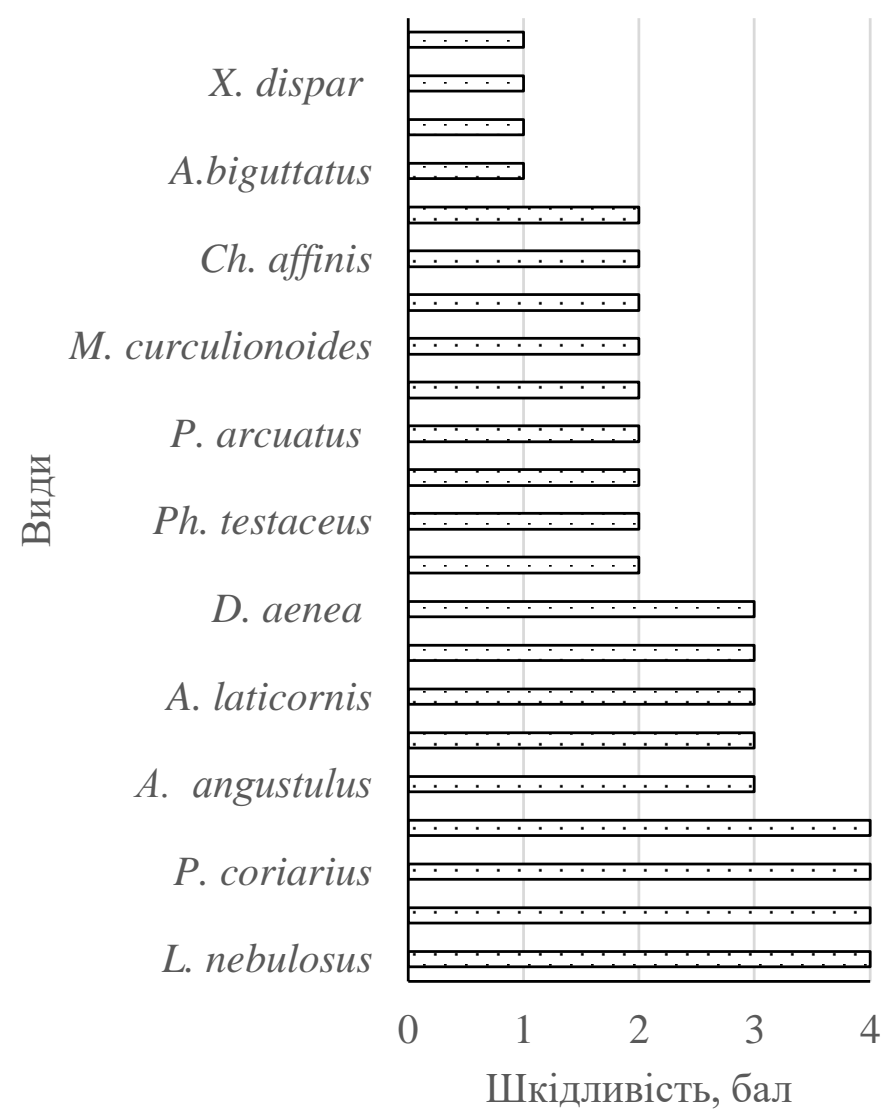

Puc. 1. Потенційна шкідливість окремих видів підкорового ентомокомплексу (1 - особливо шкідливі; 2 - помірно шкідливі; 3 - мало шкідливі; 4 - нешкідливі)

Потенційно особливо шкідливими є чотири види $(18,2 \%) \quad-$ A. biguttatus, $S$. intricatus, $X$. dispar та $X$. saxeseni, які спроможні заселяти життєздатні дерева та спричиняти їхнє ослаблення, а також заносити збудників хвороб.

Чотири нешкідливих види $(18,2 \%)-L$. nebulosus, Poecilium alni та Prionus coriarius та A. quercus заселяють мертві дерева, сприяючи 
розкладанню деревини й кругообігу речовини в лісовій екосистемі.

Решта видів - мало шкідливі (5 видів, або 22,7 \%) або помірно шкідливі (9 видів, або 40,9 \%).

Водночас, як було показано під час вивчення комах-ксилофагів сосни [19], фактична шкідливість цих видів залежить від їхнього поширення. За низького трапляння потенційно шкідливі види не $\epsilon$ шкідниками.

Аналіз свідчить, що найбільш у досліджених насадженнях найбільшою мірою поширені вусачі $P$. arcuatus, $P$. detritus, $S$. scalaris, $M$. curculionoides, Ph. testaceus (8-11\%) (рис. 2).

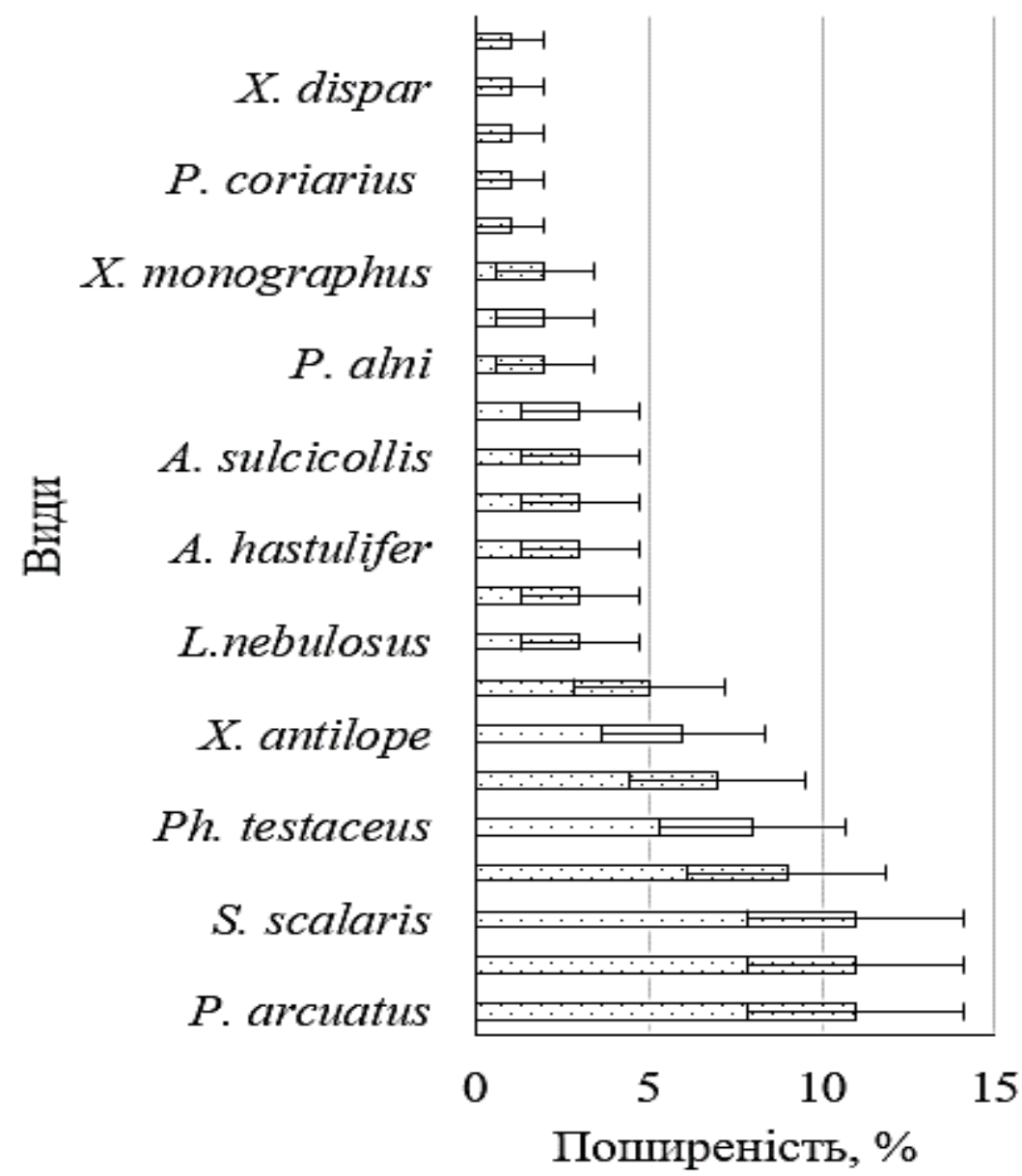

Puc. 2. Поширеність окремих видів комах-ксилофагів

Поширеність потенційно особливо шкідливих видів - златки A. biguttatus та заболонника S. intricatus доволі висока (7 і $5 \%$ відповідно), а інших небезпечних видів $X$. dispar та $X$. saxesen - - низька (лише по $1 \%)$.

Поширеність помірно шкідливих видів становить від $1 \%$
C. scopolii до $11 \% \quad P$. arcuatus, $P$. detritus та S. scalaris (див. рис. 2).

Мало шкідливі види загалом мало поширені. Це - златки роду Agrilus (крім A. biguttatus) $-3 \%$ i D. aenea $(2 \%)$.

Поширеність нешкідливих видів загалом низька (1-3 \%) (див. рис. 2). 


\section{ОБГОВОРЕННЯ}

Фауністичні дослідження в національних природних парках зазвичай спрямовані на з'ясування структури ентомокомплексів регіону на ділянках із мінімальним втручанням людини [22]. Водночас відомо, що у роки стихійних лих, зокрема посух i ураганів, у лісі накопичується багато ослаблених, а також зламаних або вирваних із коренем дерев, які $\epsilon$ принадними для заселення ксилофагами [14]. За великої кількості такого субстрату агресивні ксилофаги багаторазово збільшують чисельність, ослабляють сусідні життездатні дерева, а потім заселяють їх. Існують два суперечливі погляди на таку ситуацію: з одного боку, без втручання людини і без додавання принадного субстрату (залишків від санітарних рубок) осередок комахксилофагів через декілька років згасає [18], а з іншого боку, вчасне вилучення заселених дерев до вильоту потомства запобігає поширенню осередку [16]. Подібні дослідження найчастіше проводили у ялинових лісах Свропи [18]. У листяних лісах вони практично відсутні [22]. Тому в межах національних природних парків, де виділені зони заповідна, стаціонарної рекреації, регульованої рекреації та господарська [5], дослідження загрози поширення комах-ксилофагів $є$ дуже важливими.

У цьому дослідженні виявлено 22 види комах-ксилофагів, які вже відомі в регіоні $[2-6,8,12,13,21]$. Уточнено їхню спроможність заселяти різні породи дерев i дерева різного життєвого стану. 3 погляду збереження біорізноманіття комахи, що спроможні заселяти різні породи дерев, $є$ менш небезпечними, а мішані ліси є стійкішими до заселення агресивними видами комах у порівнянні з однопорідними (чистими) насадженнями. Серед виявлених нами комах-ксилофагів сім видів траплялися кожен лише на одній породі, проте стосовно шести 3 них $\epsilon$ відомості про їхню спроможність заселення також інших порід $[12,13$, 21].

Найбільш небезпечними ксилофагами для дерев є такі, які заселяють найбільш життєздатні дерева [9]. 3 цього погляду серед виявлених комах є чотири небезпечних види. Два види (короїди родів Xyleborus sp. i Xyleborinus sp.) прогризають ходи у деревині й одночасно заносять міцелій грибів, яким живиться їхне потомство. Такі дерева втрачають життєздатність, а деревина - якість, i може бути обмежено використана у господарстві [21]. Небезпека інших двох видів, що заселюють життєздатні дерева (S. intricatus та A. biguttatus), підсилюється тим, що їхні ходи розташовані перпендикулярно судинам, а також тим, що вони здійснюють додаткове живлення листям чи пагонами живих дерев i спричиняють їхне додаткове ослаблення [8]. При цьому в дерева можуть потрапити збудники хвороб, зокрема судинних мікозів, як це відбувається під час додаткового живлення заболонника S. intricatus [22].

Зазначені чотири види є найбільш небезпечними (див. рис. 1), проте поширеність лише $S$. intricatus та A. biguttatus є порівняно високою (див. рис. 2).

Серед помірно шкідливих видів доволі поширеними (11\%) $\epsilon$ 
P. arcuatus, P. detritus i $S$. scalaris (див. рис. 2). Водночас усі вони заселяють сильно ослаблені дерева, які і так приречені на загибель. Ходи цих комах завширшки до 10 мм розташовані у заболоні на глибині 22,5 см, що певною мірою відбивається на якості деревини. Водночас, на значній території НПП «Гомільшанські ліси», де заборонені господарські заходи, технічна шкідливість цих комах не має великого значення.

Одержані дані є підгрунтям для зіставлення у подальшому особливостей видового складу та шкідливості комах-ксилофагів на території національного природного парку, де виділені зони з різними режимами господарювання.

\section{ВИСНОВКИ}

1. У листяних лісах НПП «Гомільшанські ліси» виявлено 22 види комах-ксилофагів, які належать до 16 родів родин Cerambycidae (Вусачi), Buprestidae (Златки) та підродини Короїди (Scolytinae) родини Довгоносики (Curculionidae).

2. П'ять видів (X. antilope та златки роду Agrilus sp.) виявлені лише на дубі, D. аепеа лише на в'язі, a решта - на різних листяних породах.

3. Найбільш життєздатні дерева заселяли S. intricatus i A. biguttatus, a також - короїди родів Xyleborus sp. i Xyleborinus sp. Вусач A. quercus заселяв всихаючі дерева, а вусачі $P$. alni та P. coriarius - лише загиблі дерева.

4. Виявлені види комах-ксилофагів за потенційною шкідливістю розподілені на чотири групи. По- тенційно особливо шкідливими $\epsilon$ чотири види $(18,2 \%)-A$. biguttatus, $S$. intricatus, $X$. dispar та $X$. saxeseni. Помірно шкідливі 9 видів, або 40,9\%, малошкідливі - 5 видів, або $22,7 \%$, нешкідливі - 4 види, або $18,2 \%$.

5. Поширеність

A. biguttatus та заболонника S. intricatus доволі висока (7 і $5 \%$ відповідно), а інших небезпечних видів X. dispar та $X$. saxesen - низька (лише по $1 \%$ ). Серед помірно шкідливих видів найбільш поширені $P$. arcuatus, $P$. detritus та $S$. scalaris $(11 \%)$.

\section{Список використаних джерел}

1.Atramentova, L.A., Utevskaya, O.M. (2008). Statistical methods in biology. Gorlovka.

2. Bartenev, A. F. (2009). Longhorn beetles of the Left Bank of Ukraine and Crimea. Kharkiv.: KhNU named after V.N. Karazin.

3. Bartenev, A.F, Terekhova, V.V. (2006). Notes on the longhorn beetles (Coleoptera, Cerambycidae) of the National Nature Park «Gomolshansky Forests». Research in the territories of the Kharkov Nature Reserve Fund. 2, 39-43.

4. Bartenev, A.F., Terekhova, V.V. (2011). Additions and comments on the fauna of longhorn beetles (Coleoptera, Cerambycidae) of the Left Bank Ukraine and Crimea. Bulletin of the V.N. Karazin Kharkiv National University. Series: Biology, (13), 133-146.

5. Klimov, A.V., Vovk, O.G., Filatova, O.V. et al. (2007). The project of organizing the territory of the National Nature Park «Gomolshansky Forests», protection, renewal and recreational use of its natural complexes and objects. Kharkov: Ukrainian Research Institute of Ecological Problems.

6.Martynov, V.V., Pisarenko T.A. (2003/2004). Ecological and faunistic review of longhorn beetles (Coleoptera, Cerambycidae) of South-eastern Ukraine. The Kharkov Entomological Society Gazette, 11 (1-2), 44-69.

7. Methodical recommendations for the survey of the foci of stem forest pests (2011) / compiled by V. L. Meshkova. Kharkov: UkrNDILGA, 2011.

8. Meshkova, V. L., Kukina, O. N. (2011). Injuriousness of xylobionts in the oak clear-cuts in the Left-Bank Ukraine. Proceedings of St. Petersburg Forestry Academy, 196, 238-245

9. Mozolevskaya, E. G. (1974). Evaluation of stem pests' injuriousness. Science Papers of Moscow Forest and Technical Institute, 65, 124-132. 
10. National Nature Parks (2013). Ecology Handbook: A teaching method. tool. / contribution. O.G. Lanovenko, O.O. Ostapishina. Kherson: PE Vyshemirsky V.S.

11. Skrylnik, Yu. Ye. (2013). Injuriousness of longhorn beetles (Coleoptera, Cerambycidae) in pine stands of the Left-bank Ukraine. The Bulletin of Kharkiv National Agrarian University, Series Entomology and Phytopathology, 10, 148-159.

12. Terekhova, V. V., Salnitskaya, M. A. (2014). Annotated list of bark beetle species (Coleoptera: Curculionidae: Scolytinae) of the forest-steppe zone of Left Bank Ukraine. Bulletin of the VN Karazin Kharkiv National University. Series: Biology, 20 (1100), 180-197.

13. Terekhova, V. V, Skrylnyk, Yu. Ye. (2014). The first results of the study of jewel beetles (Coleoptera, Buprestidae) of the National Nature Park «Dvurechansky». Bulletin of the V.N. Kharkiv National University Karazin. Ser .: Biology, (19), 46-51.

14. Bouget, C., \& Duelli, P. (2004). The effects of windthrow on forest insect communities: a literature review. Biological Conservation, 118(3), 281-299. DOI: 10.1016/j.biocon.2003.09.009

15. Davydenko, K., Vasaitis, R., Meshkova, V., Menkis, A. (2014). Fungi associated with the red-haired bark beetle, Hylurgus ligniperda (Coleoptera: Curculionidae) in the forest-steppe zone in eastern Ukraine. European Journal of Entomology, 111(4), 561.4. doi: 10.14411/eje.2014.070

16. Galko, J., Økland, B., Kimoto, T. et al. (2018). Testing temperature effects on woodboring beetles associated with oak dieback. Biologia, 73, 361-370 (2018) doi:10.2478/s11756-018-0046-1

17. Holuša, J., Foit, J., Knížek, M., Schovankova, J., Lukášová, K., Vanicka, H., ... \& Kula, E. (2019). The bark beetles Orthotomicus laricis and Orthotomicus longicollis are not pests in Central Europe: a case study from the Czech Republic. Bulletin of Insectology, 72(2), 253-260. ISSN 1721-8861

18. Leidinger, J., Seibold, S., Weisser, W. W., Lange, M., Schall, P., Türke, M., \& Gossner, M. M. (2019). Effects of forest management on herbivorous insects in temperate Europe. Forest ecology and management, 437, 232-245. https://doi.org/10.1016/j.foreco.2019.01.013

19. Meshkova, V. L. (2017). Evaluation of harm (injuriousness) of stem insects in pine forest. Scientific Bulletin of UNFU, 27(8), 101-104. doi: 10.15421/40270816

20. Meshkova, V. L. Achievements and problems of forest entomology in Ukraine (2018). The Kharkov Entomol. Soc. Gaz., 26 (1), 119-129.

21. Skrylnik, Yu., Koshelyaeva, Y., Meshkova, V. (2019). Harmfulness of xylophagous insects for silver birch (Betula pendula Roth.) in the left-bank forest-steppe of Ukraine. Folia Forestalia Polonica, Series A-Forestry, 61 (3), 161-175. DOI: 10.2478/ffp-2019-0016.

22. Vodka, S., Konvicka, M., \& Cizek, L. (2009). Habitat preferences of oak-feeding xylophagous beetles in a temperate woodland: implications for forest history and management. Journal of Insect Conservation, 13(5), 553.

\title{
UDC 595.76
}

\section{XYLOPHAGOUS INSECTS OF THE DECIDUOUS TREE SPECIES IN THE NATIONAL NATURE PARK GOMILSHANSKY LISY (FORESTS)}

\author{
Bieliavtsev M.P., Meshkova V.L.
}

The aim of the research was to determine the ecological features and to evaluate the harmfulness of the most common xylophagous insects at the territory of the National Nature Park «Gomilshansky Forests». In deciduous forests of the National Nature Park «Gomilshansky Forests», 22 species of xylophagous insects from 16 genera of three families have been found, i.e. longhorn beetles (Cerambycidae), jewel beetles (Buprestidae) and bark beetles (Curculionidae: Scolytinae). The vast majority of species are polyphages. Five species (Xylotrechus antilope, Agrilus biguttatus, A. hastulifer, A. laticornis and A. sulcicollis) were found only in the English oak, Dicerca (Dicerca) aenea was found only in the elm, and other xylophagous insects were found in different deciduous trees. The jewel beetle Agrilus biguttatus, the bark beetles Scolytus intricatus, Xyleborus dispar, Xyleborus monographus and Xyleborinus saxeseni colonized the most vital trees. The longhorn beetle Anisorus quercus colonized drying up trees, and the longhorn beetles Poecilium alni and Prionus coriarius colonized only dead trees. Potential injuriousness of each species was evaluated considering both physioogical injuriousness and technical injuriousness. Four species (18.2\%) - A. biguttatus, S. intricatus, Xyleborus dispar and Xyleborinus saxeseni - are potentially the most harmful with the frequency of occurrence $7 \%, 5 \%, 1 \%$, and $1 \%$ respectively. Among 9 moderately harmful species (40.9\%), the most spread are Plagionotus arcuatus, P. detritus and Saperda scalaris (11\% each). Slightly harmful are 5 species, or $22.7 \%$, harmless are 6 species, or $18.2 \%$. The data obtained are the basis for further comparing the species composition and harmfulness of xylophagous insects in the zones with different management regimes of the national nature park.

Key words: longhorn beetles, jewel beetles, bark beetles, harmfulness, frequency of occurrence.

Стаття надійшла 20. 10. 2019 р. Рекомендована до друку на засіданні редакційної колегії після рецензуванн 